This article is available in PDF-format, in colour, at:

http://www.wydawnictwa.ipo.waw.pl/materialy-wysokoenergetyczne/materialy-wysokoenergetyczne12_1/HEM_0110_E.pdf

Materiaty Wysokoenergetyczne / High Energy Materials, 2020, 12 (1), 133 - 143; DOI 10.22211/matwys/0110E ISSN 2083-0165

Copyright (C) 2020 Eukasiewicz Research Network - Institute of Industrial Organic Chemistry, Poland

(C) $\$($ Article is available under the Creative Commons Attribution-Noncommercial-NoDerivs 3.0 license CC BY-NC-ND 3.0

Research paper / Praca doświadczalna

First published in Polish in 2015.

\title{
Theoretical and experimental investigations on a rocket propulsion system of projectiles intended for vehicle active protection system
}

\section{Teoretyczno-doświadczalne badania rakietowego układu napędowego antypocisku systemu ochrony aktywnej pojazdów}

\author{
Zbigniew Surma'), Zbigniew Leciejewski ${ }^{1, *)}$, Arkadiusz Dzik ${ }^{2)}$, Marek Białek ${ }^{2)}$ \\ 1) Military University of Technology, Faculty of Mechatronics, Armament and Aerospace, \\ 2 gen. S. Kaliskiego Street, 00-908 Warsaw, Poland \\ 2) “GAMRAT” Sp. z o.o. Special Production Plant, 108 A. Mickiewicza Street, 38-200 Jasto, Poland \\ *E-mail: zbigniew.leciejewski@wat.edu.pl
}

\begin{abstract}
The paper presents the results of a research project carried out at the Military University of Technology aimed at designing a technology demonstrator of an active protection system - a smart counter-projectile for combating anti-tank missiles at a fixed distance from the protected object. Since the design of the counter-projectile head includes electronic components sensitive to high loads, a solid propellant rocket motor was used as the propulsion system. Based on the specification and requirements for the propulsion system, the propellant charge and nozzle dimensions were determined, and the performance properties of the designed system (chamber pressure, thrust with time and total thrust pulse), calculated.

The tests and analyses were carried out using the known properties of homogenous solid rocket propellants manufactured in Poland. To verify the results of the theoretical analysis, experimental studies were carried out in collaboration with "GAMRAT" Sp. z o.o. Special Production Plant (Jasto, Poland) to validate the selected solid propellant and the initial assumptions made on the operation of the propulsion system of the designed counter-projectile.

Streszczenie: $W$ artykule zaprezentowano wybrane wyniki realizowanego $w$ Wojskowej Akademii Technicznej projektu badawczego, którego celem jest wykonanie demonstratora technologii systemu ochrony aktywnej pojazdów oraz jego elementu w postaci inteligentnego antypocisku stużacego do zwalczania pocisków przeciwpancernych $w$ ustalonej odlegtości od ochranianego obiektu. Ze względu na specyfikę konstrukcji głowicy antypocisku zawierajacej elementy elektroniczne, wrażliwe na duże przeciażenia, zdecydowano się zastosować jako uklad napędowy antypocisku silnik rakietowy na paliwo state. Na podstawie określonych wymagań (zatożeń) w stosunku do układu napędowego antypocisku wyznaczono wymiary tadunku napędowego oraz bloku dyszowego, a następnie przeprowadzono obliczenia charakterystyk pracy projektowanego ukladu (ciśnienie gazów w komorze spalania i ciag silnika w funkcji czasu, impuls całkowity ciagu).
\end{abstract}

Analizy i badania przeprowadzono przyjmując znane właściwości homogenicznych statych paliw 
rakietowych produkcji krajowej. $W$ celu weryfikacji wyników analizy teoretycznej zrealizowano we wspótpracy z ZPS „GAMRAT” Sp. z o.o. w Jaśle doświadczalne badania na hamowni, które potwierdzily prawidłowość doboru paliwa oraz postawione na wstępie założenia dotyczace dziatania uktadu napędowego projektowanego antypocisku.

Keywords: propulsion system, counter-projectile, solid rocket propellant, active protection system Stowa kluczowe: uktad napędowy, antypocisk, stałe paliwo rakietowe, system ochrony aktywnej

\section{Introduction}

A research project, no. DOBR-BIO4/031/13249/2013, co-financed by The National Centre of Research and Development (Poland), is being carried out at the Military University of Technology with the aim of designing a technology demonstrator of an active protection system for vehicles to counter enemy projectiles. On the modern battlefield, active protection can be implemented directly onto the vehicle (vehicle side zone) or at a specified distance from it [1] to reduce the risk of striking one's own forces, providing extra time to make a decision on how to protect the vehicle if the first attempt to neutralize the projectile fails. One of the components of the developed system is a smart counter-projectile for neutralizing anti-tank projectiles at a fixed distance from the protected object. As part of the research project, the Institute of Armament Technology of the Military University of Technology (Warsaw, Poland) developed a concept and designed, manufactured and tested a counter-projectile propulsion system. At the concept analysis stage, a series of laboratory projectile models were tested for possible use in the developed active protection system [2,3]. Due to the specific design of the counter-projectile head, which includes electronic components sensitive to high loads, a solid propellant propulsion system for the rocket motor was used. The design and operating requirements for the counter-projectile (Table 1) were used in the ballistic calculations. Figure 1 shows the cross-section of the counter-projectile including the rocket propulsion system.

Table 1. Design and operational requirements for the counter-projectile

\begin{tabular}{|l|c|c|}
\hline \multicolumn{1}{|c|}{ Parameter } & Unit & Value \\
\hline Projectile head mass, $m_{g}$ & \multirow{2}{*}{$\mathrm{kg}$} & 2.50 \\
\cline { 3 - 3 } & & 2.00 \\
\hline Rocket engine mass (body without solid rocket propellant), $m_{s r}$ & $\mathrm{~m}$ & 0.081 \\
\hline Rocket engine outer diameter, $D$ & $\mathrm{~m} / \mathrm{s}$ & 150 \\
\hline Maximum projectile velocity (rocket engine shut down), $V_{\max }$ & $\mathrm{m}$ & 15 \\
\hline Maximum distance from the protected object at which the rocket engine shuts down, $X$ & $\mathrm{~s}$ & 0.2 \\
\hline Maximum rocket engine operation time, $t_{p}$ & \multicolumn{2}{|c|}{} \\
\hline
\end{tabular}

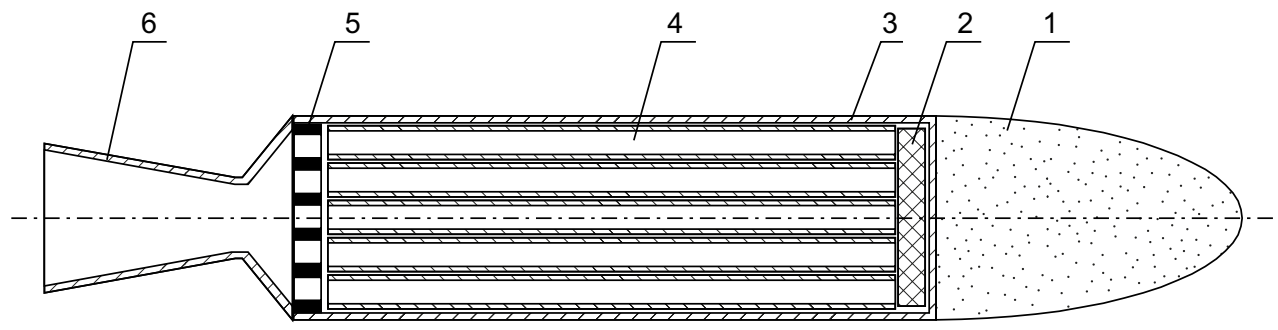

Figure 1. Cross-section of the designed counter-projectile: 1 - head, 2 - primer, 3 - rocket engine body, 4 - solid rocket propellant, 5 - grate, 6 - nozzle

Due to short its operation time, the counter-projectile propulsion system will act as a booster rocket. The rockets contain solid propellant charge which burn circumferentially along their outer surfaces. Such charges are characterized by a small combustible layer thickness $\left(e_{1}\right)$ (limiting their operating time compared to sustain motors) and a high combustion surface area $(S)$, providing much higher thrust. 
Based on the known energy-ballistic properties of the Polish composite solid rocket propellants (Szron, Nefryt, Marmur 3D and Bazalt 2a) manufactured by "GAMRAT" Sp. z o.o. Special Production Plant in Jasło (Poland) and the selected dimensions of the propellant and nozzle block, the performance of the propulsion system e.g. changes in chamber pressure and thrust with time (among others) was calculated. Changes in rocket propellant combustion rate as a function of initial temperature were analysed. On the basis of this analysis, Bazalt 2a propellant was selected for further testing of the propulsion system.

To validate the results of theoretical analysis, experimental laboratory tests of the prototype propulsion system were carried out on a motor test bench. The performance of the developed design, including chamber pressure, thrust, operation time and total thrust pulse, are in accord with the initial assumptions.

\section{Ballistic analysis of the propulsion system}

\subsection{Propellant and nozzle performance}

To ensure a large combustion surface area of the propellant charge, it was decided that it would consist of 7 tubular propellant grains with low combustible layer thickness (Fig. 2).

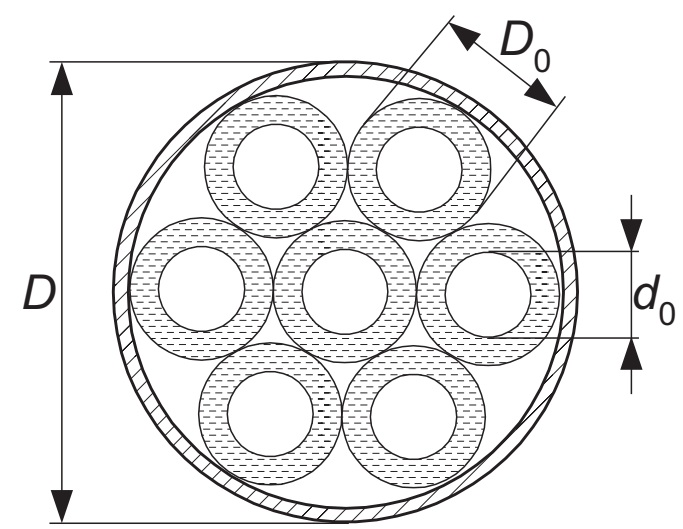

Figure 2. Cross-sectional area of the rocket engine combustion chamber with propellant including 7 tubular propellant grains

Based on the structural-operational specification of the counter-projectile (Table 1) and ballistic and physical properties of the composite solid rocket propellants - Szron, Nefryt, Marmur 3D and Bazalt 2a (Table 2), the basic properties of the propellant and nozzle were determined based on a standard procedure [4] and included in Table 3.

Table 2. Ballistic and physical properties of solid rocket propellants

\begin{tabular}{|l|c|c|c|c|c|}
\hline \multirow{2}{*}{\multicolumn{1}{|c|}{ Parameter }} & \multirow{2}{*}{ Unit } & \multicolumn{4}{c|}{ Propellant } \\
\cline { 3 - 6 } & & Szron & Nefryt & Marmur 3D & Bazalt 2a \\
\hline Pressure function coefficient, $A$ & $\mathrm{~m} /\left(\mathrm{s} \cdot \mathrm{Pa}^{\mathrm{n}}\right)$ & $128.4 \cdot 10^{-6}$ & $1.19 \cdot 10^{-6}$ & $24,0 \cdot 10^{-6}$ & $3.30^{-6} \cdot 10^{-6}$ \\
\hline Pressure function exponent, $n$ & - & 0.276 & 0.565 & 0.376 & 0.526 \\
\hline Adiabatic exponent, $k$ & - & \multicolumn{5}{|c|}{1.25} \\
\hline Propellant density, $d$ & $\mathrm{~kg} / \mathrm{m}^{3}$ & 1580 & 1580 & 1580 & 1620 \\
\hline
\end{tabular}


Table 3. Propellant and nozzle parameters for analysed rocket propellants

\begin{tabular}{|c|c|c|c|c|c|}
\hline \multirow{2}{*}{ Parameter } & \multirow{2}{*}{ Unit } & \multicolumn{4}{|c|}{ Propellant } \\
\hline & & Szron & Nefryt & Marmur 3D & Bazalt 2a \\
\hline Minimum nozzle diameter, $d_{\mathrm{m}}$ & $\mathrm{mm}$ & 18.0 & 19.0 & 15.5 & 25.0 \\
\hline Number of propellant grains, $N$ & pes. & \multicolumn{4}{|c|}{7} \\
\hline Propellant grain inner diameter, $d_{0}$ & \multirow{4}{*}{$\mathrm{mm}$} & \multicolumn{4}{|c|}{16.4} \\
\hline Propellant grain outer diameter, $D_{0}$ & & \multicolumn{4}{|c|}{22.8} \\
\hline Propellant grain length, $L_{0}$ & & \multicolumn{4}{|c|}{170} \\
\hline Propellant grain combustion layer thickness, $e_{1}$ & & \multicolumn{4}{|c|}{1.6} \\
\hline
\end{tabular}

\subsection{Pressure, thrust and operation time under normal conditions}

Based on the propellant's properties (Table 2) and propellant and nozzle dimensions (Table 3), the internal ballistics problem was solved for the solid propellant rocket motor by comparative calculations of basic performance of the system (changes in chamber pressure $(p)$ and thrust $\left(R_{w}\right)$ in time $(t)$ ) for the analysed rocket propellant. The calculations were carried out at the Ballistics Laboratory of the Institute of Armament Technology of the Military University of Technology; Figures 3 to 6 show the $p(t)$ and $R(\mathrm{t})$ curves. A continuous line denotes changes in pressure $p$ whereas a broken line denotes changes in thrust $R$.

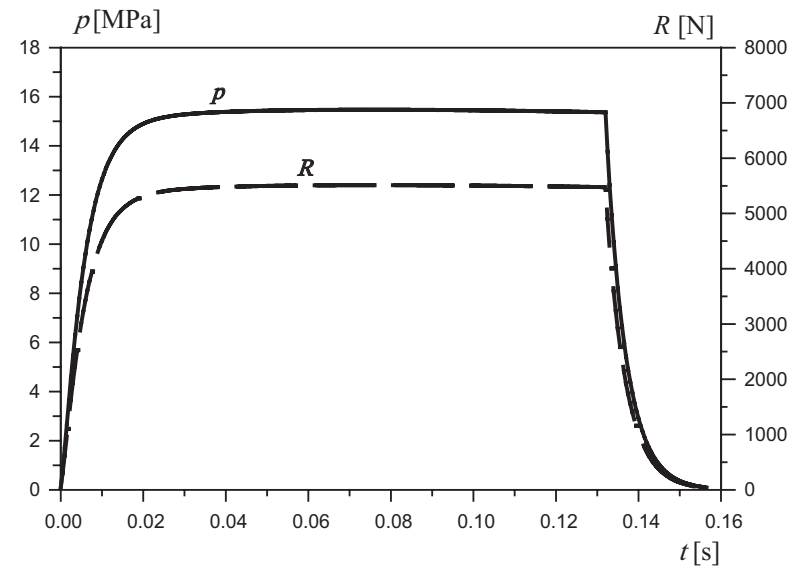

Figure 3. $p(t)$ and $R(t)$ curves for Szron propellant

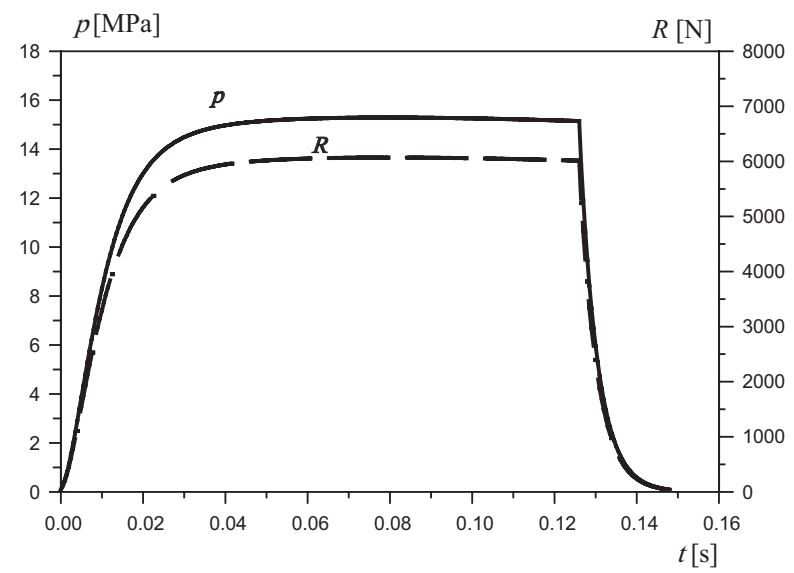

Figure 4. $p(t)$ and $R(t)$ curves for Nefryt propellant 


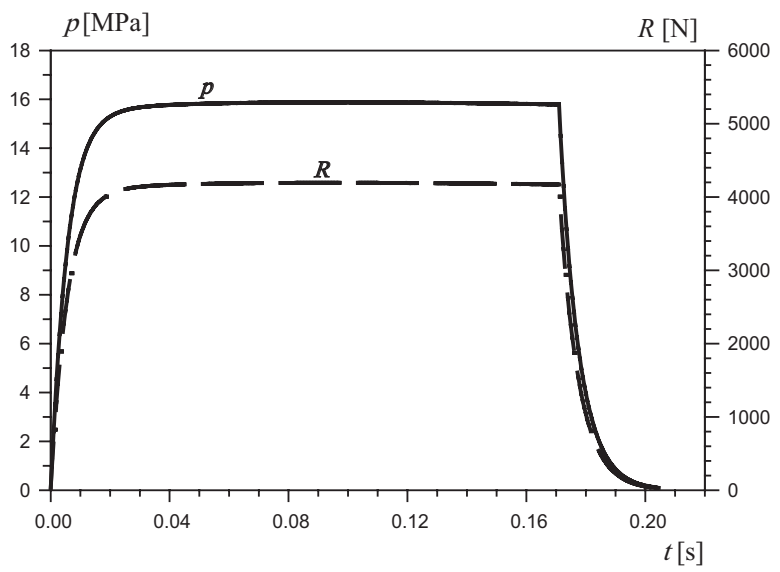

Figure 5. $p(t)$ and $R(t)$ curves for Marmur 3D propellant

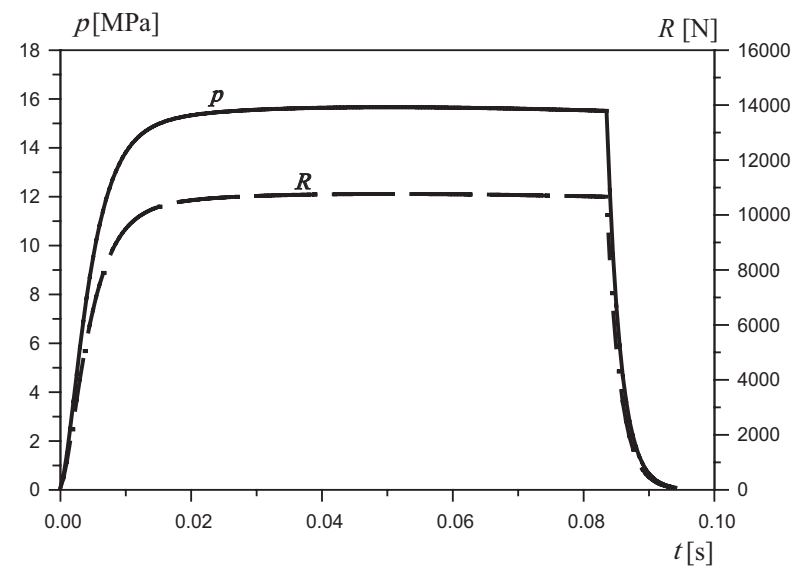

Figure 6. $p(t)$ and $R(t)$ curves for Bazalt 2a propellant

The calculations show that Bazalt 2a meets the required operating time and performance of the rocket motor, at a wide operating temperature range $(-35)-50{ }^{\circ} \mathrm{C}$. To validate the applicability of Bazalt 2a propellant in the system, the temperature function of the propellant must be determined to evaluate the effect of initial propellant temperature on the combustion rate, and the operating time of the propulsion system.

\subsection{Evaluation of the effect of initial Bazalt 2a propellant temperature on combustion rate}

The phenomenon of increase in combustion rate with increase in initial temperature of composite (non-modified) rocket propellant $\left(T_{0}\right)$ is well known, and the effect of temperature on the combustion rate can be described using a temperature function [5] as a ratio of the combustion rate $\left(u_{\mathrm{T} 0}\right)$ at a specific initial charge temperature $\left(T_{0}\right)$ to the combustion rate $\left(u_{\mathrm{TON}}\right)$ at normal charge temperature $\left(T_{0 \mathrm{~N}}\right)$ :

$f_{1}\left(T_{0}\right)=\frac{u_{T_{0}}}{u_{T_{0 N}}}$ 
Due to the very short estimated operating time of the rocket motor, the specific value of the temperature function remains practically unchanged during the operation of the rocket motor, and the calculations may use a permanent correction factor in the pressure function:

$\bar{f}(p)=A_{1} \cdot p^{n}$

where: $A_{1}=A \cdot f_{1}\left(T_{0}\right) ; A, n$ - coefficient and exponent of the pressure function of the combustion rate law, depending on the propellant type.

The tests to evaluate the effect of the initial propellant temperature on the combustion rate, involved combustion in the laboratory rocket motor of the rocket propellant samples with identical geometry and weight and different initial temperatures $\left(-35,15\right.$ and $\left.50^{\circ} \mathrm{C}\right)$. For each initial rocket propellant temperature, nozzles with different critical cross-sectional area were used to achieve different chamber pressures. The chamber pressure, rocket thrust and operation time of the rocket motor were recorded during the tests. The tests were carried out at "GAMRAT" Sp. z o.o. Special Production Plant in Jasło. The combustion rate was determined based on the combustion layer thickness and the rocket propellant combustion time during the tests.

Figure 7 shows the combustion rates for Bazalt $2 \mathrm{a}$ calculated at different initial temperatures, expressed as characteristic markers for specific chamber pressures. The graph includes power trend lines, with the exponent similar to the pressure function exponent $(n=0.526)$.

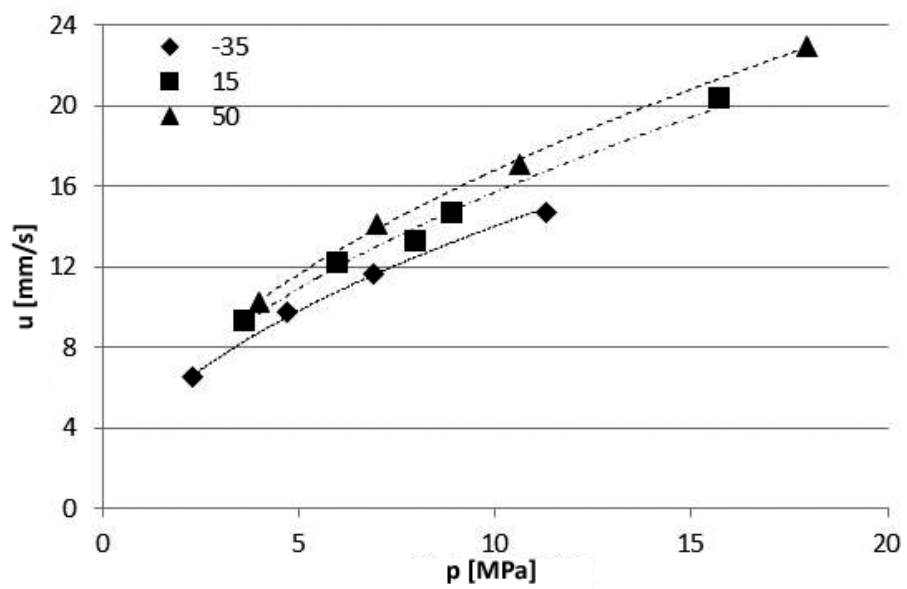

Figure 7. The relationship between the combustion rate, gas pressure and initial temperature of Bazalt 2a rocket propellant

The trend line equations (for the analysed temperatures) enabled the determination of the combustion rate for selected common gas pressures; the characteristic values of the temperature function of Bazalt 2a rocket propellant were determined using Equation 1 for the analysed temperature range (Fig. 8). This shows that, at extreme operating temperatures, the temperature function value changes by approximately $90-110 \%$ compared to the function at normal temperature. During operation at specific equilibrium pressure, based on Equation 2, a $10 \%$ increase in combustion rate can be expected at the initial propellant temperature of $50{ }^{\circ} \mathrm{C}$, and a $10 \%$ decrease in combustion rate at the initial propellant temperature of $-35{ }^{\circ} \mathrm{C}$. Decreasing the combustion rate will extend the rocket motor operation time, and should not exceed the maximum operation time of the counterprojectile motor $\left(t_{p}=0.2 \mathrm{~s}\right)$. 


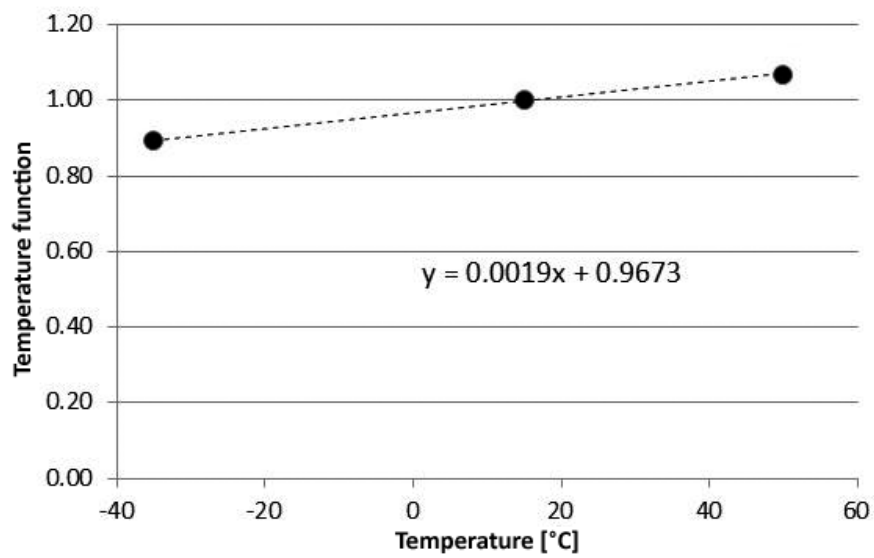

Figure 8. Temperature function curve for Bazalt 2 a propellant at a temperature range of $(-35)$ to $50{ }^{\circ} \mathrm{C}$ including the trend line equation

The relationship between the combustion rate $u$, pressure $p$ and temperature $T_{0}$ must be considered at the design and operation stage for all motor designs. The operational performance analysis of the rocket motor for a wide range of operating temperatures at different initial propellant temperatures is a key stage of the propulsion system design process.

\subsection{Erosion function}

The flow of gasses along the outer combustion surfaces of the propellant grains may significantly affect the combustion rate, and thus the chamber pressure and thrust $[6,7]$. The effect of gas flow on the combustion rate can be allowed for by using the erosion function $(\varphi(w))$. It allows correlation of the combustion rate $(u)$ of the propellant with the chamber pressure, initial propellant temperature and gas flow rate. In relation to the motors with charges combusted on the outer surfaces, the combustion rate $u$ relationship (combustion rate law) can be formulated as Equation 3.

$u=A p^{n} \cdot f_{1}\left(T_{0}\right) \cdot \varphi(w)$

The highest chamber pressures can be achieved at the initial stage of propellant combustion, and the pressure $\left(p_{\max }\right)$ at the erosion peaks may be significantly higher than anticipated, and in some cases may result in combustion chamber failure. Rocket motors designed for a higher working pressure than the threshold pressure of the propellant used (combustion on the outer surfaces), with a highly packed chamber $(\varepsilon)$ may show erosive instability during operation.

At the propulsion system design stage, a practical general indicator of the erosion stability is the following condition (Pobiedonoscew criterion) correlating the initial combustion surface area $\left(S_{0}\right)$ of the propellant and the initial cross-sectional area of the flow channel $\left(F_{\mathrm{p} 0}\right)$.

$\kappa_{0}=S_{0} / F_{p 0} \leq \kappa_{\mathrm{dop}}$

For typical solid rocket propellants and a working pressure range $\kappa_{\mathrm{dop}}=200-220$.

For multi-grain propellants, the following stability indices are formulated for:

a) internal channels

$\kappa_{\text {wew }}=4 \cdot L_{0} / d_{0}$ 
b) space between grains

$\kappa_{\text {zew }}=\left(4 \cdot N \cdot D_{0} \cdot L_{0}\right) /\left(D_{k}^{2}-N \cdot D_{0}^{2}\right)$

where: $D_{k}$ - internal combustion chamber diameter $\left(D_{k}=0.070 \mathrm{~mm}\right)$.

The stability indices were determined based on the Equations 4-6 and data included in Table 3. For the proposed rocket propulsion system design:

$\kappa_{0}=59,35$

$\kappa_{\mathrm{wew}}=41,46$

$\kappa_{\text {zew }}=86,06$

which, considering the discussion, may indicate that even though erosion combustion may be observed, erosive instability should not occur in this case.

\section{Experimental laboratory tests of the system using Bazalt 2a propellant}

To verify the results of the analyses carried out in section 2 and to validate the concept of the counter-projectile propulsion system design and the use of Bazalt 2a propellant, the experimental tests were carried out on the motor test bench. "GAMRAT" Sp. z o.o. Special Production Plant manufactured the solid rocket propellant charges whose properties are given in Table 4; a laboratory test bench was assembled and the experimental tests carried out [8]. The motor performance tests were carried out at three initial temperatures $t_{0}:-35,16$ and $50{ }^{\circ} \mathrm{C}$; changes in chamber pressure and thrust in time were recorded.

Table 4. Geometry and mass of Bazalt 2a propellant grains used in the experimental tests

\begin{tabular}{|l|c|c|}
\hline \multicolumn{1}{|c|}{ Parameter } & Unit & Value \\
\hline Propellant grain mass, $m$ & $\mathrm{~g}$ & 54.70 \\
\hline Propellant grain inner diameter, $d_{0}$ & $\mathrm{~mm}$ & 16.42 \\
\hline Propellant grain outer diameter, $D_{0}$ & $\mathrm{~mm}$ & 22.84 \\
\hline Propellant grain length, $L_{0}$ & $\mathrm{~mm}$ & 170 \\
\hline
\end{tabular}

Figures 9-11 show the typical chamber pressure $p$ curves and rocket motor thrust $R$ curves at three different initial temperatures $t_{0}$. A continuous line denotes changes in pressure $p$ whereas a broken line denotes changes in thrust $R$. Table 5 shows the characteristic test results.

Table 5. Average experimental test results (engine test bench)

\begin{tabular}{|c|c|c|c|c|c|c|c|}
\hline \multirow{2}{*}{$\boldsymbol{t}_{\mathbf{0}}\left[{ }^{\circ} \mathbf{C}\right]$} & $\boldsymbol{p}_{\max }$ & $\boldsymbol{p}_{\text {average }}$ & $\boldsymbol{I}_{\mathrm{cp}}$ & $\boldsymbol{R}_{\max }$ & $\boldsymbol{R}_{\text {average }}$ & $\boldsymbol{I}_{\mathrm{cR}}$ & $\boldsymbol{t}_{\mathbf{p}}$ \\
\cline { 2 - 8 } & {$[\mathbf{M P a}]$} & {$[\mathbf{M P a}]$} & {$[\mathbf{M P a} \cdot \mathbf{s}]$} & {$[\mathbf{N}]$} & {$[\mathbf{N}]$} & {$[\mathbf{N} \cdot \mathbf{s}]$} & {$[\mathbf{s}]$} \\
\hline-35 & 13.0 & 8.5 & 1.16 & 9460 & 5920 & 804 & 0.14 \\
\hline 16 & 19.2 & 12.8 & 1.17 & 14200 & 8640 & 823 & 0.10 \\
\hline 50 & 24.5 & 17.6 & 1.19 & 18700 & 12030 & 849 & 0.07 \\
\hline
\end{tabular}




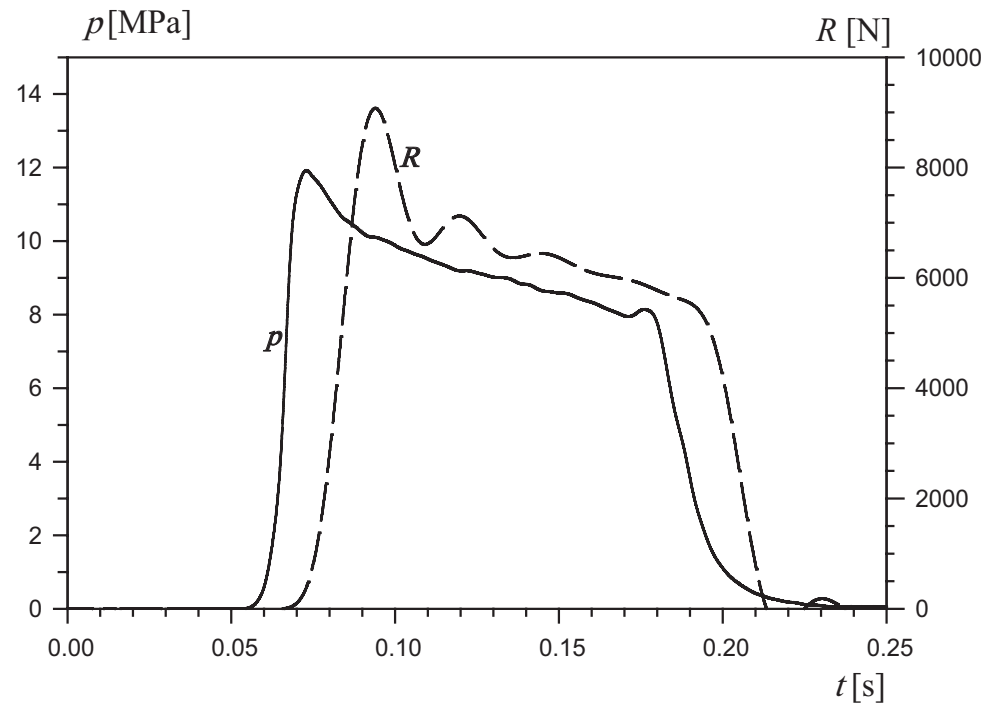

Figure 9. $p(t)$ and $R(t)$ curves at initial propellant temperature $t_{0}=-35^{\circ} \mathrm{C}$

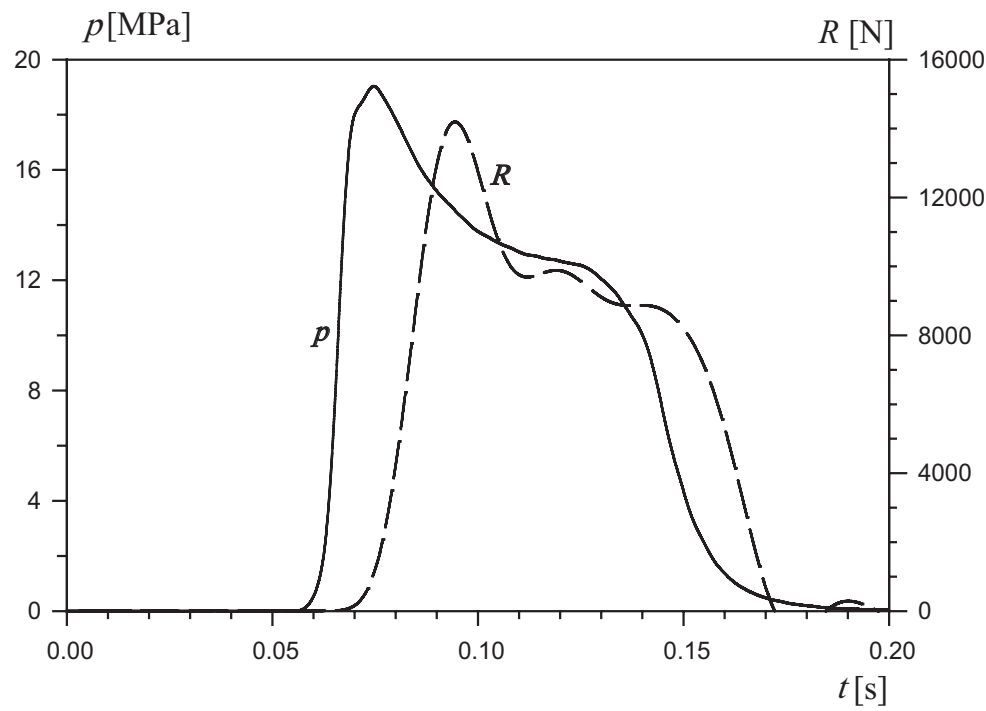

Figure 10. $p(t)$ and $R(t)$ curves at initial propellant temperature $t_{0}=16{ }^{\circ} \mathrm{C}$ 


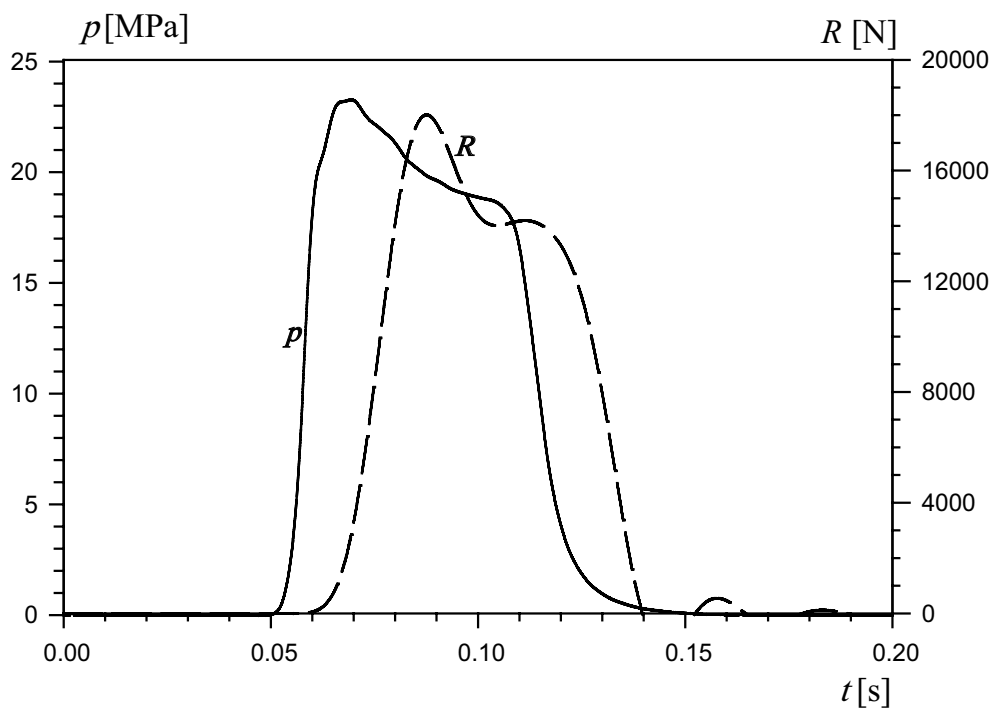

Figure 11. $p(t)$ and $R(t)$ curves at initial propellant temperature $t_{0}=50^{\circ} \mathrm{C}$

\section{Conclusions}

The following conclusions can be drawn from the results of the theoretical analysis and the experimental tests of the propulsion system using Bazalt 2a propellant:

1. The analysis of the applicability of composite solid rocket propellants and selection of Bazalt 2a as a propellant for the designed counter-projectile rocket propulsion system, validated the initial assumption regarding operating time (below $0.2 \mathrm{~s}$ ) and the total thrust pulse allowing the projectile to accelerate to at least $150 \mathrm{~m} / \mathrm{s}$.

2. Despite a practically neutral combustion surface of tubular Bazalt 2a propellant grains, the combustion pressure is not constant; the pressure peaks are probably due to erosion combustion at the initial operation stage, indicated by the Pobiedonoscew parameter values. This phenomenon may be an advantage, since higher pressure results in higher combustion rate and, as a result, shorter combustion and motor operating times.

3. The designed propulsion system is not affected by erosive instability.

\section{Acknowledgements}

The project was co-financed by the National Centre for Research and Development (Poland) as part of the project no. DOBR-BIO4/031/13249/2013.

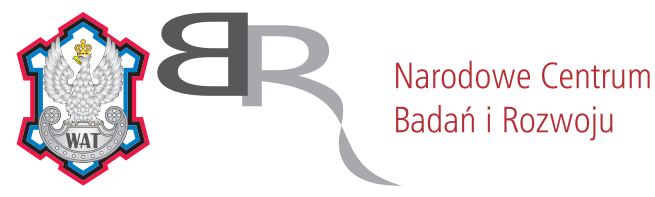

\section{References}

[1] Kupidura P., Leciejewski Z., Panowicz R., Surma Z., Trębiński R. Experimental and Model Scale Tests of an Additional Protection Structure Against RPG Rockets. Zeszyty Naukowe Instytutu Pojazdów - 
Mechanika, Ekologia, Bezpieczeństwo, Mechatronika 2012, 3(89): 81-88.

[2] Kołodziejczyk D., Kupidura P., Leciejewski Z., Panowicz R., Surma Z., Zahor M. Counterprojectile for Active Protection System. Proc. 27th Int. Symp. Ballistics, Freiburg, Germany, 2013, 1904-1913.

[3] Kupidura P., Leciejewski Z., Surma Z., Trębiński R., Zahor M. Selected Test Results for Projectile Models for Active Protection System. (in Polish) Proc. $19^{\text {th }}$ Int. Scientific Technical Conf. - Problemy Rozwoju, Produkcji i Eksploatacji Techniki Uzbrojenia, Jachranka, Poland, 2013, 92.

[4] Gacek J., Kupidura P., Leciejewski Z., Surma Z., Zahor M. A Concept of Rocket Propulsion System for Counter-projectiles Used in Active Protection Systems. (in Polish) $7^{\text {th }}$ Scientific and Technical Conf. Development Perspectives of Polish Manufactured Rocket Propulsion Systems, Small-Arms and Artillery Ammunition, Kołobrzeg, Poland, 2015.

[5] Weiss J., Torecki S., Majewski S. Fundamentals and Design of Solid Propellant Rocket Engines. (in Polish) Warsaw: Wyd. WAT, 1966.

[6] Torecki S. Rocket Motors. (in Polish) Warsaw: WKit, 1984; ISBN 83-206-0470-2.

[7] Leciejewski Z. Combustion Performance of Elongated Propellant Charges in Solid Propellant Rocket Engine. (in Polish) PhD Thesis, Military University of Technology, Warsaw, Poland, 1993.

[8] Białek M., Cholewiak A., Dzik A. Production and Testing of Bazalt 2 A Elements. (in Polish) "Gamrat" Special Production Plant, Research Study Report, Jasło, Poland, 2015.

Polish version:

The study was originally published in Polish, in the Materiaty Wysokoenergetyczne (High Energy Materials) journal 2015, 7: 44-52.

English version:

- Revised: November 21, 2020

- Published first time online: December 16, 2020 